\title{
Obituary
}

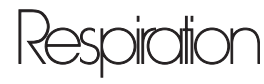

Published online: February 18, 2015

DOI: $10.1159 / 000377648$

\section{In Memoriam Professor Heinrich Herzog}

Respiration has the sad duty to inform its readers about the death of the founder and mentor of this journal: Professor Dr. Heinrich Herzog-Christ died in his 95th year on December 18, 2014.

Heinrich Herzog was born in 1920 and grew up in Zollikon on the shores of the Lake Zurich, then a village close to the City of Zurich, where he graduated in medicine. Doing his military service while still a student, he contracted pleurisy, and when nasty complications arose, he was sent to a sanatorium in Davos. This chance encounter with a 'Lungenheilstätte' (lung clinic) laid the path along which his scientific career was later to develop: he published an investigation on the X-ray appearance of the hilar region. The Swiss National Society of Radiology awarded him a prize for this paper which was also to serve as his doctoral thesis.

The young physician was keen to spread his wings and began to explore the scientific world of pulmonary research at the time. He began his journey in Geneva and in Chur, but before very long he was spending time in the USA, the UK and France, where he made friends for life with many who were later viewed as part of the scientific elite.

Professor Paul Sadoul (Nancy, 1914-2011) in France was a close contemporary of Heinrich Herzog, and their lives show a surprising number of parallels. With their own distinct personalities they had at that time a formative influence on the practise of pulmonary medicine: Professor Sadoul promoted (patho-)physiology and research on lung function, while Professor Herzog was drawn to the rapidly evolving clinical, diagnostic and therapeutic aspects of pneumology.
By 1950, Heinrich Herzog was back in Switzerland and before too long landed up in Basel - where he was to stay for good. Here he met his future wife, Dorothea Christ, a young and highly motivated historian of the fine arts, who throughout her life was involved in museums and the Staatsarchiv in Basel. They got married in 1951. Unfortunately their wish to have children was not fulfilled. They spent almost 60 years together in wonderful harmony, until Dorothea died in August 2009.

Professor Herzog's academic career centered around the Bürgerspital (later Kantonsspital), i.e. the Basel University Medical School, which was his 'home' from now on. His mentor, Professor Hans Straub, was quick to sense the abilities of his new coworker. In 1959, Professor Herzog was appointed a 'Privatdozent' (Associate Professor), and in 1960 the running of the Lung Division was entrusted to him. After a short but demanding training in bronchology (Paris) he became Professor of Medicine in 1963.

From this point on, there was an almost never-ending influx of young colleagues looking for a teacher with a record of high qualities in scientific achievement, lecturing, training skills and with a good sense of humour. In the ensuing years, quite a few of his former students could be found in leading positions at university clinics and hospitals in Germany, Switzerland and Austria.

Over and above his merit as a scientist, clinician and teacher, he impressed me with his virtues that sprang from his wisdom, cheerfulness and empathy and made him a caring physician, who was the 'best friend' of his patients. He anticipated intuitively everything that is said and published nowadays on the practise of medical ethics. 
The long life of Professor Herzog also bore fruit in the way in which he fulfilled his role as an editor. When he took over the Schweizerische Zeitschrift für Tuberkulose und Pneumologie in 1962, he renamed it Medicina Thoracalis, until in 1969 the current title emerged: Respiration.

During just a few years in the 1960s, the European scene of pneumology experienced a dramatic shift away from phthisiology towards physiology, from the remote mountain valleys into the cities, and from sanatoria into universities, where pneumology was accepted and installed as a (sub-)specialty of internal medicine - much to the mutual benefit of science and teaching. It now emerged that Professor Herzog was already right there at the heart of the matter at the Bürgerspital with his Department of Pneumology (or 'pneumono-logy', as was his wont to correct us) in close contact with cardiology, infectiology and the up-and-coming intensive care, which was initially based on Bird Respirators. The mainstay of his clinic, though, remained bronchoscopy, X-ray (tomography) and a sophisticated lung function laboratory.

A new era in the life of Professor Herzog began when initiatives were started to contact the highly motivated pneumologists behind the Iron Curtain. He and Paul Sadoul, Erik Berglund (Sweden), Severin Daum and Jiri Widimsky (Prague, Czech Republic) courageously founded the Societas Europaea Physiologiae Clinicae Respiratoriae (SEPCR) in Prague in 1966. After the end of the 'Prague Spring' in 1968, Severin Daum and his family were expelled from the country and one day arrived in Basel. They were welcomed at the house of the Herzogs and provided with everything that was necessary to cover their immediate needs. Professor Herzog arranged for Severin Daum to work in the lung function laboratory in Basel for 2 years, until he could move on - as planned - to Munich.

As mentioned above, Heinrich Herzog, the dedicated clinician, felt the need for more patient-oriented research that would extend beyond the scope of SEPCR, which was more or less centered around pathophysiology. It seemed to him that a complementary clinical endeavor could bridge the gap between the laboratory and the patient. So, he and other clinicians sat down and founded the Societas Europaea Pneumologica (SEP). The almost immediate success and growth of SEP was taken as clear support for this enterprise. Its first congress in Basel in 1984 with Professor Herzog presiding was a remarkable success. From now on, SEP was considered a legitimate sister of SEPCR, and this was demonstrated by the wonderful congress of SEP/SEPCR in London in 1990, which eventually led to the founding of the European Respiratory Society (ERS, 1990). In spite of the fact that the new ERS had come up with its own European Respiratory Journal, Heinrich Herzog - by then already an Emeritus Professor - kept the standards of Respiration at a high level.

In 1997, he decided to step down as Editor-in-Chief and placed Respiration in the hands of Professor Chris Bolliger (1998). He witnessed with delight the enormous productivity of his talented follower and observed the rise of 'his' Respiration with great satisfaction. Chris' early and totally unexpected death must have been a severe shock to him. The rapid and highly competent takeover by F.J.F. Herth as new Editor-in-Chief may have been of some comfort to him.

In the course of the last 25 years, his beloved wife and companion of a lifetime progressively lost her eyesight, and he was keen on reading books to her - which she clearly preferred to audiobooks which were gaining in popularity. When she died in 2009, Heinrich Herzog did not give up. Disciplined as ever, he followed a daily schedule as long as possible. He died peacefully on December 18,2014 . His memory will persist in the minds and hearts of very many friends, colleagues and trainees.

Univ. Prof. Dr. Friedrich Kummer 